\title{
Egy német énekeskönyv margójára
}

Több mint négy évtizede, az 1970-es évek közepén, nagyapáméknál töltöttem egy augusztusi hétvégét, a falu túlsó végén. Nem volt ez ritkaság, szerettem ott lenni, a szüleim pedig általában megengedték, hogy péntek este, vagy szombat reggel átköltözzem két napra a Rákóczi utcába. (Hol az unokatestvéreimmel, hol a húgommal, de sokszor csak egyedül.) Otthonos, nagyszülöisen meleg hangulat volt ott. Esténként sötétzöld csomagolású grúz tea illata, 60 wattos félhomály a konyhában, vajas-hagymás-paprikás kenyér reggelire. Hagyományos, sorba rendezett helyiségekből álló szép, verandás parasztház volt a nagyszüleimé, árnyékot adó öreg, göcsörtös törzsủ körtefákkal, virágoskerttel (rózsa, orgona, hóvirág, nárcisz, kulcsvirág), a hátsó udvarban istálló, gazdasági épületek, górék, majd pedig egy szőlőskert. Kutya, macska, ló, tehenek a játékos borjaikkal, disznók és kismalacok, látszólag hergelésre született kotlós tyúkok az el-elkószáló kiscsibékkel.

Ezen a hétvégén azonban történt valami, ami miatt ez a forró nyári nap kicsit más lett, mint a többi kalácsillatú vasárnap délután, s így számomra a személyes emlékezet egyik fontos pontjává vált. Ebéd után, már a szüleimmel és a testvéremmel együtt kint ültünk a verandán, amikor elérkezettnek láttam az időt arra, hogy beszámoljak a családnak legújabb felfedezésemről. Én ugyanis minden alkalommal végigkutattam a házat pincétől a padlásig, így jobban tudtam, hogy a régi papírok, tárgyak közül mi hol van, mint a nagyszüleim. Egy hely azonban addig elkerülte a figyelmemet. A kamrában volt egy magas polc, legfelül papa szüleinek nagyméretü, utólag kiszínezett fényképei, fentről lefelé lekvárok, befőttek, konyhai eszközök. A legalsó részt valamiért nem vizsgáltam át addig alaposan.

Egy nagyon szép, öreg, rézlapokkal fedett vastag, furcsa betüs könyvet találtam ott előző délután, amit kapcsok fogtak össze, s aminek az elején egy Luther Mártont, a libáját, és a német nyelvre lefordított bibliát ábrázoló metszet volt. Bár nem tudtam elolvasni, annyit azért kivettem, hogy 1870-ben nyomták Aradon. Odaadtam nagyapámnak. (Ö akkoriban ugyan alig volt pár évvel idősebb, mint most én, de én természetesen már öregembernek tartottam, még ha büszke is voltam rá, hogy milyen erős, és hogy mennyire jól tartja magát.) Nagyanyám persze méltatlankodott egy sort a turkálás miatt, de ez csak a „kötelező kör” volt, valójában ő maga sem gondolta komolyan a korholást, azt azonban - mint hasonló esetben mindig - tudatosítani akarta bennem, hogy amit tettem, az nem helyes.

* A szerző történész, a Társadalomtudományi Kutatóközpont Kisebbségkutató Intézet fömunkatársa. E-mail: Eiler.Ferenc@tk.hu 
Tehát a könyv. Mint kiderült, ez a dédapám német evangélikus, gót betüvel szedett énekes- és imádságos könyve volt (németül Gesang- und Gebetbuch), amit még édesapjától örökölt, s aminek az első lapjára - hasonlóan felmenőjéhez - ő is szorgalmasan bejegyezte a családtagok születési és halálozási dátumait. Legkésőbb a második világháború után kerülhetett a polc alá, attól kezdve ugyanis nem volt többé német nyelvü istentisztelet Soltvadkerten. (Egy ideig valószínüleg az sem volt tanácsos, hogy valaki egy közösségi térben megszólaljon ezen a nyelven, annak ellenére, hogy a helyi német származású lakosság annyira elmagyarosodottnak számított már, hogy még a két világháború közötti német szervezetek sem fordítottak energiát arra, hogy foglalkozzanak a településsel.)

Mezőberény, Bulkesz, Gyoma, Harta, Szemlak és Vadkert német evangélikusai énekeltek pár évtizede még ebből az énekeskönyvből. Amikor a településekről kérdeztem nagyapámat, csak egy volt (persze szülőhelyén, Soltvadkerten kívül), amiről többet tudott, mert ott járt, és voltak onnan származó ismerősei is. Egészen belemelegedett, amikor elkezdett mesélni a tölünk kb. 40 km-re fekvő dunamenti faluról, Hartáról. Kiderült, hogy a hartaiak tulajdonképpen a testvéreink, mert az őseink egy része onnan települt át a falunkba. (Nem mellesleg ott is, itt is erős evangélikus közösség élt.) Csak az a különbség - folytatta -, hogy ök ragaszkodnak a német anyanyelvükhöz, mi pedig, néhány öregasszony kivételével, már csak magyarul beszélünk - mondta. Nem igazán értettem, hogy ha ez így van, és sajnálja is, akkor miért nem tanult meg a szüleitől németül, s miért csak egy-két mondatot tud, s azt is csak kínos mosolygással kísérve adja elö, mint aki tisztában van vele, hogy ez azér' nem az igazi... Így alakult - mondta. Pedig a mama nagyon erőltette, még a „pofonfát is megráztam” néha - nevetett. De az iskolában magyarul tanultunk, sőt a szünetekben is magyarul játszottunk. Egyszerüen nem volt már olyan nyilvános tér, ahol mi gyerekek németül beszéltünk volna. Persze ebben volt egy kis lázadás is a mama akarata ellen, aki akkor még németül beszélgetett a barátnőivel. (Végül a hadifogságban csak megtanult egy kicsit németül a vele együtt raboskodó császártöltési barátjától, akkor és ott, amikor és ahol már nem is volt rá szüksége. Érdekes, hogy ő, a vadkerti, valószínüleg császártöltési nyelvjárásban hadart németül...)

Hartán ez nem így van, ott még ma is beszélnek németül - folytatta. Igaz, amit mi elkerültünk, az a hartaiaknak nem sikerült - mondta rezignáltan. A háború után rengeteg családot összeszedtek, és marhavagonokban szállították ki őket Németországba. A földjeiket, házaikat elvették, még csak ki sem fizették őket. (Úgy emlékszem, hogy a részletekbe ekkor még nem ment bele. Talán azért, mert a felnőttek ismerték az összefüggéseket, én pedig valamiért nem kérdeztem vissza.) Micsoda földek vannak ott, nem ám úgy, mint nálunk, a rengeteg homok! - mesélt tovább nagyapám. (Vadkert abban az időben kimondottan jómódú falunak számított, de neki mégis az járt a fejében, hogy mit el nem tudnának érni a vadkerti parasztok, ha ilyen gyönyörü fekete földjeik lennének.) Azok a termelőszövetkezetek! És a 
falu! Kövesút mindenütt, a járdák lebetonozva. A hartaiak most is évtizedekkel elöttünk járnak!

Itt vége szakadt a beszélgetésnek, nem tudom miért. Talán kihozta a mama a kalácsot a konyhából, talán összevesztünk a húgommal, s a hangzavarban lekerült a téma a napirendröl... Aztán több mint 3 évtizeddel később - a nagyszüleim már régen nem éltek - írtam egy könyvet a hartai németek 20. századi történetéről. Azért Hartáról, mert a falu ettől a beszélgetéstől kezdve ismeretlenül is fontossá vált számomra. Meg talán azért is, hogy ezzel letudjak egy adósságot, elhitetve magammal, hogy az embernek nem is kell feltétlenül írnia a saját szülőfalujáról... 